\title{
Mannlige verdier i antikken og deres tilsynekomst kontra fravær i De eleusinske mysteriene
}

\author{
EVY JOHANNE HÅLAND
}

ENGLISH ABSTRACT: The following article consists of two parts. The first part deals with male values in ancient Greece, based on a comparative approach using material from similar contemporary Mediterranean societies, first and foremost the cultural pattern connected with 'honour and shame'. The next part discusses how these male values are present or absent in the Eleusinian mysteries. So, although the following study mainly focuses on male values by giving a definition of and describing the actual values, the female values in the Greek societies are, necessarily, also discussed.

NORSK RESUMÉ: Den følgende artikkelen er i to deler. Første delen behandler mannlige verdier $i$ antikkens Hellas, ut fra en komparativ innfallsvinkel som nytter materiale fra lignende moderne mediterrane samfunn, forst og fremst forestillingene knyttet til 'ære og skam'. Den andre delen diskuterer hoordan disse verdiene kommer til syne eller legges til side i De eleusinske mysteriene. Det betyr at selv om det følgende hovedsakelig fokuserer på mannlige verdier, gjennom definisjon og beskrivelse av disse, må også de kvinnelige verdiene i samfunnet behandles.

KEYWORDS: Ancient and Modern Greece, Mediterranean anthropology, Honour and shame, Male/Female values, Fertility-rituals/-cult, Eleusinian mysteries 


\section{1: Mannlige verdier i antikken}

Hvordan skal en definere mannlige verdier i antikken ${ }^{1}$

Majoriteten av de skriftlige kildene vi har fra antikken er produsert av menn, som representerer en intellektuell elite. Kan en da regne med at de ikke representerer folk flest? Er det slik at filosofene er eksponenter for 'mannlige elitistiske verdier' versus det 'vanlige folk generelt' trodde? Hvordan kan en da forklare at mannlige verdier også kunne være folkelige, og at de intellektuelle var en del av det samfunnet som de levde i?

Hvordan kan en forklare at selv om f.eks. Adonisfesten var et rituale som på mange måter står i opposisjon til den offisielle kulten, og det er hevdet at polis (bystaten) verken påbyr eller finansierer disse orgiene (Schol. Ar. Lys. 389), har vi likevel innskrifter som kan vitne om at mennene også har bidratt økonomisk til hustruenes feiring. ${ }^{2}$ Hvordan kan en forklare paradoksene eller selvmotsigelsene i de mannsproduserte kildene, slik som når den intellektuelle Plutark på den ene siden fordømmer magi, og forbinder det med 'overtroiske' personer (Mor. 164e-171f), vanlige folk, utlendinger og kvinnfolk, på den annen side godtar magi? Som en typisk representant for folkelige og tradisjonelle verdier råder han den unge gifteklare Eurydike til å spise et kvedeeple så hun er sikker på å bli gravid. Slik inkarnerer Plutark to forskjellige verdisyn, som begge vel må være mannlige. ${ }^{3} \mathrm{Ja}$, hva er egentlig mannlige verdier?

\section{Mannlighetens ære}

Blant flere typiske kulturtrekk i dagens middelhavsområde, er Æren den fremherskende sosiale verdi. Den agonistiske natur i alle sosiale forbindelser er også viktig, likedan betydningen av den sosiale gruppens godkjennelse av det en gjør, familielivets natur, og kvinnens og mannens forskjellige roller. Disse kulturtrekkene representerer modeller for sosial sammenligning og analyser som har en nær tilpasning til det antikke kildematerialet. Dette hjelpemiddelet gir nye spørsmål som vi kan stille de antikke kildene gjennom en komparativ prosess mellom moderne og antikke forhold, f.eks. når det gjelder definisjonen på mannlige verdier.

Blant den tradisjonelle middelhavsantropologiens viktigste resultater, finner en forestillingene knyttet til ære og skam, dvs. kulturelle oppfatninger rundt kjønnsroller,

1 Den følgende artikkelen er basert på den obligatoriske prøveforelesningen jeg hadde for Doktorgraden ved Universitetet i Bergen i 2005. Emnet var: Definér mannlige ikke-elitistiske verdier i antikken og drøft i hvilken grad disse mannlige verdier kommer til syne eller legges til side i De eleusinske mysteriene. Selv om artikkelen hovedsakelig tar for seg mannlige verdier, trekkes også de kvinnelige verdier inn. Disse siste blir definert og grundig beskrevet i Håland 2007. Tematikkens relevans mht. forholdet mellom offisiell- og folkekult behandles også i et upublisert bokmanus: Håland 2008a.

2 IG II² 1261, 1290, jf. Winkler 1990, 235n.9.

3 Plut. Mor. 138d1, jf. 279 f, Sol. 20. Han er også opptatt av Afrodites betydning Mor. 138cd. 
makt og seksualitet. Ære- og skamkoden presenterer et felles verdisyn blant menn i dagens område. Selv om greske kvinner i prinsippet kan samtykke i den mannlige ære- og skammodellen, har de sine egne verdier i tillegg til, eller som står i motsetning til det mannlige synet, avhengig av om den mannlige ideologien er i overensstemmelse med deres egen tankegang. ${ }^{4}$ Forestillingene rundt 'ære og skam' er vanligvis knyttet til et offisielt mannlig verdisystem, og det gjennomsyrer også antikke fremstillinger skrevet av menn fra Hesiod, Platon, ${ }^{5}$ via Aristoteles og talere til Plutarks og senere skrifter. Ifølge disse konvensjonelle mannlige verdiene er kjønnsrelasjonene i samfunnet romlig delt, kvinnen forbindes med husholdningen, oikos, hjemmesfæren og huset der hun sitter ved veven, mens mannens domene er utesfæren og det offentlige polis. I middelhavsverdenens patriarkalske familieideologi har kvinner og sladder potensielle samfunnsødeleggende krefter, derfor blir de også fryktet, og må holdes på plass, gjerne gjennom erobring. En møter en serie av antiteser omkring polariseringen av mannlige og kvinnelige roller. Lov, orden, styring, fornuft, og kultur assosieres med menn, mens kvinner forbindes med de motsatte kvaliteter: rituale, kaos, vanstyre, ufornuft, følelser og natur. Kvinnen er forbundet med, og gjerne vurdert som en kropp og assosieres med jorden. Mannen er forbundet med de motsatte kvaliteter som hode, fallos eller lys. Ifølge dette mannlige verdisystemet, assosieres kvinner med de negative sider av slike symbolske motsetninger som venstre versus høyre, hekseri-magi versus religion i dag. Kvinner er svakere og mer tilbøyelige til å synde. De bærer byrden av seksualitetens ødeleggende kraft som må bli kanalisert innen mannlig kontrollerte grenser for å tjene de sosialt ønskelige målene for reproduksjonen.

Vi møter de samme patriarkalske skillene i den antikke kildeproduksjonen, siden antikke menn gir den samme polare oppfatning av kvinnelighetens og mannlighetens assosiering med sentrale elementer innen den kjønnsmessige todeling, og vektlegger negative aspekter ved kvinner og kvinnekroppen, som fullstendig 'skambelagt' eller 'skammelig', dens iboende forurensende natur, dens fare som en potensiell fortapelsesvei for familiens ære. En mann må ha ære, elske og respektere mandigheten. Kvinnen skal være ærbar, kysk og trofast mot ham. Kvinner skal holde seg hjemme i huset, og identiteten deres er mindre problematisk enn menns. Kvinneligheten blir ikke vunnet eller demonstrert aktivt, og de er ikke engasjert $\mathrm{i}$ offentlige forestillinger eller konkurranser slik menn er. Selve ideen om at kvinner opptrer offentlig synes motstridende til de mannlige kulturelle ære- og skamregler for passende kvinnelig oppførsel i middelhavsverdenen. Tidligere myter som presenterte kvinnelighetens fallende tilstand, karakterisert av kvinners iboende svakhet, mottakelighet for fristelser og tilbøyelighet for sensualitet, dvs. ondskapen og sluheten til mytiske figurer som Pandora og

4 For kvinnelige verdier, jf. n.1 supra. Se også Håland 2008b og infra. Håland 2007, kap. 1-2 gir en lengre presentasjon/diskusjon av middelhavsantropologiens utvikling fra 1960-tallet, f.eks. Peristiany 1966.

5 Se f.eks. Pl. Leg. 780e-781d, 790c-791b, 947b-e, 958d-960b. Se ellers Håland 2007, kap. 6 og 2008a, kap. 3-4. Ære og skam behandles alt hos Dodds 1951, kap. 1. Han er imidlertid ikke opptatt av den kjønnsmessige dimensjonen, men ser en bevegelse fra 'skamkultur' til 'skyldkultur' (kap. 2), som er kritisert av senere antropologer, se også Håland 2007, kap. 1 for diskusjon. 
Helena, gjenfinnes også i den kristne arketypen, Eva. Hennes kontrast Panagia (Jomfru Maria), reflekterer forskjellige aspekter fra gudinner, slik som Demeter, Artemis og Athene, eller for den saks skyld Plutarks idealkvinne, hans kone Timoxena (Mor. 608b$612 b)$. I liket med ham og de øvrige vitnesbyrd fra antikkens menn, presenterer også dagens menn idealet, slik de ønsker det skal være. Som følge av den tradisjonelle kvinne- og mannssfæren vi møter i området, var de antikke forfatternes forutsetninger for å fortelle om kvinner ikke særlig gode. Med få unntak var de heller ikke særlig interessert i kvinners aktiviteter, og det de eventuelt hadde å si var svært ofte farget av redsel, usikkerhet eller forakt, noe som ofte skyldtes uvitenhet. I tillegg er der i dag situasjoner når menn handler stikk i strid med sine egne mannlige ære- og skamverdier, uten at det er noe i veien for det, slik det også var i antikken, der de samme kilder som vitner om disse kjønnsmessige dikotomiene også motsier seg selv.

Plutark er representativ for grekernes logikk fordi skriftene hans er gjennomsyret av gammelt og tradisjonelt materiale, både i form av sitater fra Homer, Hesiod, tragediene, Platon, m.fl., og generell folketro, godkjent eller ikke, siden Plutarks relevans vedrørende tradisjonelle verdier, ikke utelukker hans elitistiske preg, som han også deler med de fleste andre forfatterne av de skriftlige kildene. Derfor er det vanskelig å skille mellom vanlige mannlige verdier og elitistiske verdier. Det finnes f.eks. mye folkekult hos både Aristoteles og Plutark, og mye av det en møter innen folkekulten synes også paradoksalt nok å være viktig innen den offisielle religionen. ${ }^{6}$

Kildene skrevet av den mannlige eliten presenterer mange paradokser eller selvmotsigelser både når det gjelder forholdet til det annet kjønn, slik som med de ovennevnte dikotomiene, og til andre menn, likevel kan en lære mye ved å lese mellom linjene.

I det følgende skal jeg derfor la noen eksempler fra Plutarks rike produksjon illustrere noen av de generelle mannlige verdiene som han deler med flere andre representanter for forestillinger blant menn i antikken.

På den ene siden er Plutark positiv til skikken der en tar gaver med seg på kirkegården til de forskrevne minnehøytidene (Mor. 612a), men på en moderat måte, siden han fordømmer overdådige banketter i et tilfelle (Mor. 114f-115a) og krever offer i et annet (Mor. 114d). Dette paradokset møter en også i andre sammenhenger i den mediterrane kulturen, der en på den ene siden er redd for å prale mens en på den annen side må vise alle andre hvor rik en er. Her møter en ideen om det begrensete godet, eller bondesamfunnets grunnfilosofi som uttrykkes gjennom troen på Det onde (misunnelige) øyet. Denne tankegangen hører sammen med verdenssynet i middelhavsområdet, og er en del av det sosiale språk i antikken og i dag. En har hevdet (Foster 1972) at ideen om Det onde øyet bidrar til sosial kontroll, siden folk ikke våger å vise sin velstand av frykt for at andre skal begjære den. Men faktum er at folk både frykter Det onde øyet samtidig som de paradoksalt nok elsker å prale. Derav følger nødvendig-

6 Håland 1999; Patterson 1992, 4710, 4722 for Plutarks relevans vedr. tradisjonelle verdier, vs. Blomqvist 1995. Konvensjonelle verdier hos Plutark behandles også hos Moxnes 1997. 
heten og betydningen av alle de magiske innretninger for å holde Det onde øyet i sjakk, som en også møter igjen hos Plutark både i positiv og negativ forstand, som når han (Per. 38) forteller om statsmannen Perikles, som på dødsleiet unnskyldte seg overfor en venn fordi han bar en amulett rundt halsen. Det var nemlig en av husets kvinner som hadde plassert den der. I en annen sammenheng lærer vi om gudinnen, Isis' amulett (Plut. Mor. 377b, 378b) som er svært viktig når hun er gravid og mer sårbar overfor onde krefter. Når en kvinne bærer amuletten i en slik tilstand, synes m.a.o. bruken å få en annen betydning. Som andre representanter for den mediterrane mannlige ære- og skamtradisjonen hevder Plutark at "tar du fra de fleste kvinner gullbroderte sko, armbånd, purpurklær og perler, som de elsker å prale med, ja, så viser de seg ikke utenfor døren, men holder seg hjemme i huset" (Mor. 142c30), et sted kvinner skulle holde seg, ifølge både Plutark og andre menn. Samtidig var paradoksalt nok fester og ritualer fremført av kvinner viktige, i likhet med deres daglige utendørs gjøremål. Plutark (Mor. 144c43) er også opptatt av betydningen av å ha fred hjemme før en prøver på det samme ute i det offentlige og blant venner, siden folk snarere vil legge merke til urett mot kvinner enn kvinners urett. I likhet med andre menn (Eur. Bacch.; Dem. 18), er han kritisk til og forbinder (Plut. Mor. 144c44-e45, jf. 609b) bakkanalsk ekstravaganse, hekseri, magiske kjærlighetsdrikker og amuletter med kvinner (jf. Od. 10). Selv om slike såkalte kvinnelige laster ikke var forbeholdt kvinner i antikken, er han åpenbart i overensstemmelse med i alle fall mannlige fellesmeninger, ${ }^{7}$ når det gjelder den farlige kvinnelige bruken av slike remedier, som ble ansett for å være en potensiell trussel mot den tradisjonelle sosiale orden, siden en møter det igjen i mytiske tilfeller som Helena, Deinareia og Medeia. Imidlertid vitner amuletter og magiske papyrier (PGM) om at dette ikke var så uvanlig likevel.

I antikkens Hellas sto kvinnen for fruktbarheten, mens mannen sto for det skapende aspektet, slik det også er i dagens middelhavssamfunn. ${ }^{8}$ Som i dag hevdet derfor antikkens menn at "mannen sår og kvinnen bærer."9 I overensstemmelse med ære- og skamkoden, hevder flere antikke kilder at mannen hersker over kvinnen, slik sjelen kontrollerer kroppen. ${ }^{10}$ Mot er forøvrig en mannlig egenskap (Mor. 769b-c). Dette antikke synet er en parallell til dagens versjon av det mannlige ære- og skamsamfunnets verdier som hevder at "man elsker kvinnen som nærer, mannen som beskytter."11 Parallellen, Plutark hevder at naturen har plantet følelser og omsorg for barna deres inn i mødrene (Mor. 496a-e, jf. 769b-c), og kvinner har ingen del i Ares (Mor. 761e). For Aristoteles

7 Jf. Cuffel 2005 for paralleller fra øvrige mediterrane kontekster.

8 Bourdieu 1980, 357, jf. imidlertid Plut. Mor. 364a der Osiris synes å tillegges begge aspekter, se imidlertid 375c60 der han hevder at (den kvinnelige) Naturen (jf. Isis) både er det skapende og bevarende elementet. For kvinner og fruktbarhet, se Schol. Luc. DMeretr. 2.1, Rabe 1906: 275.23-276.28, jf. Plut. Mor. 378d-f69, se også 141b-c23, Bourdieu 1980, 359; Papamichael 1975, 78, jf. 54.

9 Jf. du Boulay 1984, 553fn.1 og Arist. GA. 765b10 ff., jf. 716a14-24, 727b31-33. Se Håland 2007, kap. 6 for flere antikke kilder.

10 Arist. Pol. 1.1254b3-15; Plut. Mor. 142e.

11 Vernier 1991, 300f 
som for øvrige antikke forfattere fra Hesiod av, er jorden, kropp, mage, livmor, og menstruasjon forbundet med kvinner, som også vurderes som et kjønn. ${ }^{12}$ På tross av at kvinner skal være ærbare, ha en naturlig enkelthet, i likhet med Plutarks kone, skal de være attråverdige og begjært, en tvetydig formulering som er i tråd med vanlige ære- og skamverdier i området. Dette er en motsigelse som imidlertid er vanlig i folkelige holdninger overfor kvinner og ekteskap, slik vi møter det i kildene skrevet av menn.

Forfatterne av retoriske tekster og leserne deres gjennomgikk samme sosialiseringsnivå i barndommen. Retorikkens lovprisning, eller beskyldning, er basert på en mer fundamental kulturell virkelighet, den status man tilla begrep som 'ære og skam', som altså er en sentral antitese i verdisystemet i det mediterrane området. En bør ha logikken i den sosiale konteksten i minnet når en bruker filosofenes tekster, selv om de gjerne forvrenger realitetene.

Filosofene og talerne er altså også produkt av det samfunnet de lever i, og kan derfor fortelle en hel del om det samfunnet når en leser mellom linjene. Som Giambattista Vico har hevdet, ${ }^{13}$ er de ordene som finnes i hvert enkelt språk av bondeopprinnelse. Det er disse ordene som benyttes av både filosofer og andre lærde. Det betyr at selv om filosofene ikke er samfunnets talerør (Keesing 1981), er de likevel skapt av samfunnet, og bærer med seg dets grunnleggende verdier, som også deres nye ideologier blir tilpasset. For Aiskhylos', Nonnus' og øvrige produsenter av en stor del av de skriftlige kildene, er det folketeori som ligger bak tankene. Både Aristoteles og Plutark var godt informert om folketro og magi, og som andre smågutter ble også de formet av sine mødre, selv om de i voksen alder måtte ta avstand fra mye av dette ut fra ære- og skamsamfunnets logikk, i likhet med dagens menn. På tross av den offisielle avstandtaken, ligger det mye nedfelt mellom linjene i skriftene deres, fordi mye er innkodet som de ikke kan ta avstand fra, siden det er så selvsagt, det skal bare være slik. Følgelig kan f.eks. Plutark fordømme magi (Mor. 145b-e, 139a5, 166a) og likevel godta den (Mor. 138c-d, 143d38), særlig om den er 'hvit'. Det kan synes som om de relevante folkelige aspektene har mer å si innen det offisielle mannlige verdisystemet, som følge av dets egne underliggende og iboende verdier, enn vi egentlig er klar over, og at vi har å gjøre med et allment mannlig verdigrunnlag som er innkodet fra barnsben av (jf. Håland 2007, kap. 3).

En kan altså få et nytt perspektiv på de elitistiske utsagnene, som ofte er motstridende, ved å sammenligne dem med dagens parallelle forhold der forskjellige verdier gjerne motstrides av informantene i visse situasjoner, selv om de godtar det $\mathrm{i}$ andre. Det kommer an på situasjonen og personens rolle. Slik kan en også få en større forståelse for hvordan mange av de mannsproduserte kildene kan fordømme forskjellige religiøse skikker i én sammenheng, og selv støtte de samme ritualene i en annen.

2 Arist. GA.727a2 ff., 728b23-32, se 716a14-24, 727b31-34

13 Se Herzfeld 1992, 186 for sitat av Vico. 2,2,2,1. 
Det er umulig å sette entydige merkelapper på virkeligheten som om den skulle være hvit eller svart. Også mht. Plutark selv, ser en at menn i et ære- og skamsamfunn kan ha et motstridende verdisystem som uttrykker følelser og svakhet som er i strid med det offisielle ære- og skamparadigmet, som nedvurderer det og relaterer det til kvinner og vanlige folk. Dette oppdager en når en tar for seg forholdet mellom offisiell ideologi og menneskelig erfaring. ${ }^{14}$

Slik kan en forklare hvordan en mannlig krigerideologi som motsetter seg følelser og 'svakhet' kan eksistere i samme samfunn der en også møter en motsatt ideologi, fordi menn også elsker romantiske dikt, og gjerne gråter når de deklameres. En kan forklare dette ved å hevde at der i hvert fall er to ideologier, som hver og en gir modeller for forskjellige typer av erfaring. Slik kan en også prøve å få større forståelse for mange av tvetydighetene kildene presenterer. På den ene side møter en den mannlige ære- og skamideologi fra Hesiod til Plutark. På den annen side møter en romantiske myter og de magiske papyrer som motstrider Plutarks og andres kritiske påstander om bruken av magi eller kjærlighetsdrikker. En møter en slags 'anti-følelser' mot følelser i ære- og skamkulturen, samtidig som følelser er ekstremt viktig. Ved å være seg bevisst at det er mulig å postulere forskjellige motstridende verdisystemer, kan en forklare mange av paradoksene, særlig hos Plutark, som opererer med 'kvinnelige' kvinner som han er kritisk til, versus 'mannlige' kvinner som han er positiv til. Samme karakteristikker anvender han på menn. En kvinne som jakter på en mann er imidlertid mannlig på en negativ måte og overtrer derfor naturlovene. I visse situasjoner blir likevel mødre, krigerske på vegne av barn, hus og hjem, og gudinner kan reagere på innblandingen i sine kvinnesfæreinteresser ved å gå ut fra sin sfære og bryte ned den sosiale orden. ${ }^{15}$ Som en naturlig konsekvens av den mannlige ære- og skamideologien, er likevel klager og gråt forbundet med kvinner både når den gråtende Odysseus sammenlignes med en kvinne hos Homer (Od. 8.523-531) og senere, ${ }^{16}$ mens krigen er forbundet med menn, siden det er de som skal forsvare kvinner og barn. Fruktbarhetskult derimot, der magi er et gjennomgående trekk, har stor betydning bl.a. i forbindelse med De eleusinske mysterier, selv om denne fruktbarhetskulten ikke ble fremført av menn, da den tilhørte kvinnenes domene.

La meg summere opp det foregående med å definere de mannlige verdiene som konvensjonelle mannlige ære- og skamverdier, som imidlertid ikke utelukker, at avhengig av personens rolle, kan den samme personen likevel utmerket godt ha et motstridende verdisystem som godkjenner mangt som er stikk i strid med det offisielle

14 Vedr. kjærlighet er kvinner og menn ganske like hos Plutark (Mor. 767a-b, jf. 766 e-f og 767c) som gir karakteristikker som tilhører begge kjønn. I brevet til konen etter datterens død, er hun den som må være sterk, ellers bryter han sammen (Mor. 608c2), som i andre henseender er svært kritisk til disse 'kvinnelige uttrykksmåtene', siden tårer og klager er forbundet med kvinner, barbarer, og vanlige folk, Mor. 113a.

15 Foley 1994b, 116, 'kvinnelig-inntrenger' mønsteret.

16 Vs. en annen kontekst (Il. 22.405-436, jf. 33-89) der Hekabe og Priamos viser sterke følelsesmessige reaksjoner over Hektors død. Homer presenterer også andre klagende menn, som Akhilleus (Il. 23.12 ff.). Se Il. 9.13-15, 16.2-4 for menns vs. Od. 19.204 f. kvinners klager. 
ære- og skamparadigmet, slik som magi. Der finnes f.eks. mye folkekult og ikke-elitistiske mannlige verdier hos både Aristoteles og Plutark, som i likhet med dagens mennesker har forskjellige roller. Deres egne verdier overlapper hverandre, de både sameksisterer og konkurrerer.

I det følgende skal jeg først ta for meg i hvilken grad disse mannlige verdiene kommer til syne i De eleusinske mysteriene, deretter skal jeg ta for meg i hvilken grad de legges til side. Siden også mannlige og kvinnelige verdier kan overlappe, kommer jeg gjerne tilbake til de mannlige verdiene under diskusjonen av i hvilken grad de legges til side, og omvendt.

\section{2: De mannlige verdienes tilsynekomst kontra fravær i De eleusinske mysteriene}

De eleusinske jordbruksmysteriene var tilgjengelige for begge kjønn. Festen foregikk i en uke om høsten, og hadde innledende ritualer syv måneder tidligere. Det var en fruktbarhetsfest som skulle sikre kornets vekst, og fornye livskraften i jorden og hos dyr og mennesker. Prosesjonen mellom Athen og Eleusis med hellige fruktbarhetssymboler sto sentralt, men også forbindelsen mellom de to kjønn samt liv og død, symbolisert gjennom ekteskapet mellom Kore, dvs. jenten eller korngudinnen Demeters datter, og underverdenens hersker, Hades eller Pluton. ${ }^{17}$

\section{a) Mannlige verdiers tilsynekomst i De eleusinske mysteriene}

Gjennom ære- og skamideologien møter en forestillingen om mannlighet og handling versus kvinnelighet og mottakelighet.18 Mannlighet og handling hører sammen med betydningen av den mannlige biologiske aggressivitet eller penetrerende funksjon, jakt, krig og drap. Som nevnt, har kvinner ingen del i Ares, og den mannlige krigerideologien, som også hører sammen med den agonistiske natur i sosiale forbindelser, illustreres også i Eleusismysteriene. Dette gjelder bakgrunnen for den athenske deltakelse i mysteriene og organiseringen av festen, siden mysteriene skal presentere en kombinasjon av kult fra Eleusis, et svært fruktbart jordbruksdistrikt og fra Athen som under ekspansjonen la området under seg, sannsynligvis i det sjette århundre. Forholdet mellom Athen og Eleusis møter vi gjennom den mytiske historien som Pausanias (1.38) forteller om der Eleusis ble underlagt Athen etter erobringskrigen. Prosesjonene under

17 Se Håland 2007, kap. 5 for en presentasjon av Eleusismysteriene samt diskusjon av kilder og litteratur.

18 Jf. f.eks. Arist. GA. 716a2-24, 727b31-33, 729a9-14; Plut. Mor. 366a, 382c77. og Stehle Stigers 1981 vedr. mannlige vs. kvinnelige forfatteres mønstre for å skrive dikt, se Håland 2007, kap. 6 (særlig 371f) for flere henvisninger og diskusjon. Jf. Foley 1994b med Dubisch 1991 og Kristeva 1986 vedr. HHD. vs. Od. og mytisk kvinnelig versus historisk mannlig tid. 
festen kan bl.a. vurderes for å være rituelle gjentakelser av den athenske erobringen, siden krig, erobring og mytiske fortellinger om betydningen av å erverve seg jord, f.eks. gjennom et kongedømme kombinert med ære og status, er faktorer som hører sammen med mannlige verdier.

Administrasjonen av festen kom i hendene på athenere, og i klassisk tid ble den kontrollert av 'kongearkonten' (archon basileus), mens embetsmennene bl.a. kom fra Eumolpidai-familien, etterkommere av den eleusinske kongefamilien, foruten den athenske Kerykes-familien (eg. 'herolder'). Tjenestemennene, som var ansvarlig for det religiøse innholdet i kulten, kom hovedsakelig fra det eleusinske presteskapet. I overensstemmelse med ære- og skamsamfunnets assosiering med aspekter som lov, orden, styring og menn, sto altså menn for festens forvaltning, selv om kultpersonellet også omfattet prestinner.

Eleusismysteriene var viktig i den athenske mannlige polis. Den ideologiske forherligelsen av polis, er representert gjennom hyllingen av korngudinnen, som ifølge athenerne (Isoc. 4.28 f.) ga dem korngaven og kunsten å dyrke det, i tillegg til de hellige mysterieritualene. Dette var belønning for tjenester bare de innvidde ble fortalt.

Prosesjoner fornyer, renser og trekker generelt opp grensene for byens territorium, og prosesjonen mellom Athen og Eleusis renset også området før pløying og såtid. Gjennom en maktdemonstrasjon ble et fruktbart jordbrukslandskap under athensk herredømme og Demeters beskyttelse markert, siden riten var til gudinnens ære. Flyttingen av hiera, 'De hellige ting' fra Eleusis til Athen, og deretter tilbake igjen, markerte at Eleusis, ikke langt fra grensen til Athens rival Megara, hørte til den Athenske polis. Slik ble hele det Athen-dominerte området renset. Selve festen fornyer og stadfester den sosiale struktur innad, og forholdet mellom samfunnet og korngudinnen.

Den athenske polis' betydning møter en også gjennom våpenhvilen som ble erklært i forbindelse med festen, og at alle kunne innvies så sant de snakket gresk og hadde rene hender (Isoc. 4.157; Hdt. 8.65). Konkurransemotivet illustreres særlig gjennom gavene fra de tilbedende som, ifølge et dekret (IG I2 76), ble utstilt i Eleusis. Kanskje det også ble skrevet hvem som hadde gitt hva, og en slik kunne påvirke andre til å gi mer. Selv om det var vanlig å komme med gaver til guddommene, ble disse utstilte gavene gitt etter påbud og invitasjon fra presteskapet. Hierofanten (dvs. den som åpenbarer de hellige ting) og dadouchos (fakkelbæreren) hadde nemlig beordret athenerne og deres allierte og invitert alle andre greske poliser til å gi førstegrødeoffer (aparchai) av korn til mysteriene, "i overensstemmelse med forfedrenes skikker og orakelet i Delphi" (IG I 76.4-10). Dette er en formulering som er vanlig i antikken der en holder forfedrenes ritualer for gudene i hevd, og en kan merke seg at her gjelder de athenske forfedrenes ritualer for samtlige deltakere. En kan nok derfor hevde at festen ble brukt av makthaverne i politisk øyemed. Mannlige verdier illustreres også ved at sentrale guddommer fikk okseoffer, selv om gudinnen festen var viet generelt fikk ofre av drektige dyr. Okseoffer ble også gitt Triptolemos, den mytiske helten som fikk i oppgave å utbre korndyrkingen av gudinnen. Navnet hans betegner de tre Hellige pløyinger i 
Attika. ${ }^{19}$ Vasemalerier (fra ca. 540 f.v.t.) tyder på at han var viktig i den mannlige athenske ideologi, i konkurransen med andre poliser om hvem som først dyrket korn.

Før Eleusis ble en del av den athenske polis, var dette stedet for en lokal jordbrukskult. Visse hemmelige ritualer minnet om kornets og andre av jordens frukters årlige gjenfødelse. Den årlige vegetasjonssyklusen ble assosiert med myten om Hades' rov av Persefone eller Kore og Demeters påfølgende sorg. Legenden er bevart i den Homerske Hymnen til Demeter (HHD). Hymnen forteller om hvem som sørger for jordbrukets frukter og gir den offisielle versjonen av grunnleggelsen av mysteriekulten i Eleusis av Demeter selv. Imidlertid var det menn fra Eleusis som bygde tempelet hennes. Demeterhymnen har dype forbindelser med kulten like til det punktet at deltakerne imiterer hendelser i fortellingen gjennom mysterieritualene.

Historien som fortelles i Demeterhymnen er at underverdenens guddom, Hades, røvet Jordmoren, Demeters datter, Kore. Demeter leter forgjeves etter datteren over hele jorden, og kommer endelig til Eleusis. Her blir hun, forkledd som en gammel kvinne, mottatt i kongen, Keleus', hus for å amme sønnen hans, Demofon. Hun legger ungen i ilden hver natt for at hans dødelige natur skal brennes vekk, men blir oppdaget av Metaneira, Keleus' kone, og derfor forhindret i å gjøre ham udødelig slik hun har planlagt. Hun viser seg så for eleusinerne i all sin guddommelige herlighet, og befaler dem å bygge et tempel for henne. Gudefaren, Zeus, prøver å overtale henne til å komme opp på Olympen, og å la jorden begynne å spire igjen. Kore skal få komme tilbake til sin mor. Men Kore er bundet til Hades, og har spist frø av et granateple der nede i underverdenen. Derfor kan hun ikke komme fullstendig tilbake, men må tilbringe en del av året i underverdenen hos sin make.

Den mannlige erobringen illustreres også konkret i Demeterhymnen gjennom det rovet som starter hymnen og går som en rød tråd gjennom hele diktet: Hymnen begynner med å fortelle at det er faren, Zeus, og onkelen, Hades, som har avtalt rovet og dermed Kores bryllup over hodet på moren og datteren. Rovet kan også ha blitt rituelt fremført under innvielsesseremonien i Eleusis. Det skyldes at det andre elementet i denne tredelte seremonien, dvs. ting som blir gjort, bl.a. kan ha innbefattet konkrete mimiske gjengivelser av noen av mytene om Demeter. Flere kilder indikerer da også at sentrale elementer i Demetermyten ble omsatt i handling i helligdommen, slik som rovet på Kore (jf. Clem Al. Protr. 2.12Pff. og 2.18P), f.eks. føres Demeterprestinnen vekk for å etterligne rovet (Tert. Ad. Nat. 2.7,15). I ære- og skamkonteksten heter det at menn skal være agenten og kvinnen kun objekt for begjær, uten mulighet til motstand av egen vilje. I dag betegner en følgelig 'hentingen' av bruden som å 'ta' eller 'få' bruden (eg. pairno, dvs. ta, få). Det er imidlertid ikke alltid det går så fredelig for seg, siden bruderovet tradisjonelt har vært viktig i bryllupssammenheng. Det illustreres gjennom skikken der et forelsket par rømmer, dersom de ikke får lov til å gifte seg. Denne røm-

19 Triptolemos, dvs. tris + poleo. 
mingen omtales som ‘å stjele bruden'(klepsigamia). Etterpå er de utskjemt og må gifte seg. Det kan sammenlignes med det bruderovet som vi møter når Hades røver Kore.

I forbindelse med ekteskapsinngåelsen i antikken møter vi hentingen eller overførselen av bruden, der hun 'ledes ut' (exagoge) av farens hus eller 'ledes inn' (eisagoge) i brudgommens hus. En parallell til hentingen av bruden kan også anses for å bli rituelt fremført i Eleusismysteriene før selve innvielsen finner sted. Slik kan en betrakte seremonien to dager før den offisielle festens begynnelse. Da dro epheboi, unge menn, i prosesjon til Eleusis for å hente hiera og prestinnen til Athen. Hentingen av prestinnen og hiera er også en rituell gjentakelse av den athenske erobring, og kan derfor symbolisere Eleusis som ble underlagt Athen, siden den tapende part i en krig, underkaster seg, og betraktes som kvinnelig fra et ære- og skamperspektiv. De ledsagende ephebenes oppgave blir en parallell til rådet fra Plutark til den omtalte unge vordende brud og hennes brudgom om at "jomfruer må passes på." I likhet med andre kvinner, skal de skal også holde seg hjemme og være tause. ${ }^{20}$

Dette kan naturligvis synes paradoksalt siden tematikken der unge jenter ble røvet av menn mens de var ute på marken og plukket blomster er vanlig i antikken, ikke bare når det gjelder Kore. Ut fra den agonistiske natur i ære- og skamsamfunnets forbindelser kappes ellers krigførende parter om å erobre fiendens kvinner samtidig som mannen er en hanrei om noen erobrer hans, og betydningen av å bevare kvinnens dyd ligger bak mange slag. At en jente ikke var jomfru var en krenkelse av familiens ære. Det er ennå en alvorlig utfordring for menns ære om noen går hans husholds kvinner for nær. Bruddet på denne normen, møter en imidlertid gjennom at det ikke er faren som tar hevn i dette tilfellet, men moren, som følge av farens handling. ${ }^{21}$

Den hellige herolden i Eleusismysteriene er en parallell til bæreren av bryllupsvimpelen i senere tid, siden logikken bak bryllupsvimpelen er at den uttrykker gaveutveksling mellom to parter, venner eller fiender som søker overenskomst. Den er et symbol brukt i krig og triumfmarsj, og der er paralleller mellom å dra i felten og å hente bruden (Alexakes 1990). Det heter seg at bruden hentes slik i dag fordi foreldrene kan sette seg på bakbeina, hvilket ikke er noe nytt, slik det kommer frem i Demeterlegenden (HHD. 350 f.).

På prosesjonsdagen førte en hiera tilbake til Eleusis sammen med en statue av Iakchos, som gav sitt navn til prosesjonen. Deltakerne rope triumfropet, som var opprinnelsen til Iakchos og forbundet med Kores skrik da hun ble røvet til underverdenen. Prosesjonen kan både betraktes som en pilegrimsgang, triumfmarsj, og bryllupsprosesjon. Dette illustreres ved at mystene (dvs. en som er innvidd i mysterium) kranset seg med myrtegrener. Slik antikkens brudepar ble møtt på terskelen til deres nye hjem, ble det også utført et spesielt rituale på den tidligere grensen mellom Athen og Eleusis,

20 Plut. Mor. 381e-f, 142d31-32. Jf. Håland 2007, fig. 25: Nede i den hellige 'marmorsirkel' på den kykladiske øyen Tinos står marinegaster i stram givakt mens de holder båren med ikonet av Jomfruen.

21 Siden klassiske ideologi så ekteskapet som en forening mellom to familier innen polis, kan Kore her være et eksempel på en epikleros, dvs. hun følger arven i mangel av brødre og må gifte seg med den nærmeste mannlige etterkommeren, men siden faren slett ikke var død, er dette mindre trolig. 
som synes å ha hatt magiske hensikter i forbindelse med overgangen, siden en bandt en gul ulltråd rundt mystenes høyre hånd og venstre legg. Hierofanten åpenbarte de hellige ting under innvielsesseremonien i Eleusis. Dette ritualet kan sammenlignes med avdekkingen (anakalupteria), av bruden etter at paret kom til brudekammeret (thalamos). Hiera blir i anaktoron ('residens/palass'), den innerste helligdommen i Eleusis til neste fest, 22 og med unntak av at bare hierofanten hadde tiltrede hit, er vanligvis det innerste området $\mathrm{i}$ et hus forbundet med kvinner.

Mannlige verdier er også uttrykt gjennom betydningen av mannlige barn i hymnen og i den eleusinske kulten, slik som gjennom den eleusinske kongesønnen Demofon og det mannlige barnet fra arnen som ble innvidd for polis (IG $\left.\mathrm{I}^{2} 6 \mathrm{c}\right)$. Dette er vanlig i en mannlig ære- og skamatmosfære der det først og fremst er sønner som ønskes.

Ifølge det mannlige verdisystemet som ser religion, samfunn og familien, ut fra mannsfæren, dominerer den allmektige, olympiske Zeus gudeverdenen på samme måte som den generelle mann dominerer sitt eget oikos og mannen dominerer kvinnen. ${ }^{23}$ Likevel er de viktigste jordbruksguddommene kvinnelige eller har 'kvinnelige' karakteristikker. I tillegg spiller Kore den rollen som mannlige guddommer spiller i andre antikke samfunns myter, som den egyptiske Osiris. Dessuten er de mest sentrale ritualer i festene utført av kvinner. Det følgende skal derfor ta opp i hvilken grad mannlige verdier legges til side i Eleusismysteriene.

b) Fravær av mannlige verdier i De eleusinske mysteriene

Kan betydningen av fryktbarhetskult og kvinner i mysteriene da vitne om at de mannlige ære- og skamverdiene legges til side? Det er naturligvis like viktig for menn som for kvinner å feire fruktbarhetsfester før såtid. At en gudinne sørger for jordbrukets frukter og derfor er viet festen og kvinner i likhet med denne jordmoren har stor betydning, kan også være forenelig med ære- og skamsamfunnets dikotomi. Ifølge denne, sørger kvinner for fruktbarheten, siden mannlige kvaliteter som jakt, krig og drap står i motsetning til egenskaper som er forbundet med kvinnen, som kjærlighet, fødsel, liv, næring og omsorg.

Eleusismysteriene hadde altså en sentral plassering innen jordbrukssyklusen, og fruktbarhetskult, kvinner og det kvinnelige spilte en stor rolle i forbindelse med festen. Ut fra de mannsproduserte kildene som forteller om gangen i festen, ser en naturligvis ikke dette så klart som i øvrige Demeterfester. Kvinnene var likevel vesentlige, f.eks. gjennom det nattlige pannychis-ritualet som omfattet dans og sang som inkluderte aischrologia eller obskøn tale. Demeterprestinnen og de andre betydningsfulle kvinnene

Det kan være et tilfelle der en snur opp ned på det patrilokalske ekteskapsmønsteret der kvinnen flytter inn i mannens hus, men siden Eleusis var erobret og en del av Athen, markeres hele området under athensk dominans.

23 Pomeroy 1998, 16 vs. HHD. 156 ff. Metaneira tar avgjørelsen om å engasjere Demeter som amme, 219 ff. 
var også sentrale. Selve kulten av korngudinnen og datteren hennes vitner om morkult (jf. Håland 2006).

Når Demeter kommer til Eleusis i HHD blir hun mottatt i en genuint kvinnelig atmosfære, som også var viktig i forbindelse med mysteriene. Deler av gudinnens opphold blant dødelige kvinner blir rituelt gjentatt etter ankomsten til Eleusis da kvinnene inntok tempelet eller innvielseshallen, telesterion for en pannychis, dvs. en seremoni som varer hele natten. Ritualet kan være analogt til scenen i hymnen der kvinnene prøver å berolige gudinnen. Dessuten ble det fremført obskøniteter for å gjøre den sørgende gudinnen glad. Her hører også Demeters påbud til kvinnene om at de blander byggmel og vann med poleimynte til drikken, som hun mottar. Ut fra ingrediensenes symbolikk skal denne drikken, kykeon, ha vært en blanding av det kvinnelige og mannlige kjønnsorgan. Drikken ble også drukket av dem som ble innvidd. Sannsynligvis var det slik de brøt fasten før selve innvielsesseremonien.

Kvinnens rolle i fremførelsen av jordbruksritualene er sentral. Festene for Demeter konsentrerer seg om samfunnets rituelle oppmerksomhet overfor de kritiske punktene i jordens fruktbarhetssyklus, spesielt såtid. På en magisk måte forsøker de å influere begivenhetenes gang rituelt. Kvinnene fremfører de sentrale ritualene som følge av at de betraktes som bærere av fruktbarhetens hemmeligheter. Visse spesifikke faktorer legger vekt på kvinnens rolle i fruktbarhetsritualene. Blant sentrale aspekter som er vevd inn i temaet om jordbruksårets syklus er kvinner, hemmeligheter og obskønitet. Obskøn tale og manipuleringen med symboler formet som kvinnelige og mannlige kjønnsorganer er et vanlig middel til å oppmuntre fruktbarhetsgudinnen til å fatte mot og vende tilbake til sin egentlige oppgave. Slik stimulerer obskøniteten jorden til å føde. Ritualer preget av obskøniteter var hemmelige for menn, og ritualene skulle sikre fruktbarheten for polis. Skikken kalt gephyrismos (jf. Ar. Ran. 391 f., 416ff.), som ble fremført av menn under prosesjonen til Eleusis, kan derfor tyde på at mannlige verdier settes til side her. Alternativt, kan forbindelsen mellom kvinner og obskønitet gjøre at mennene var tildekket når de fremførte obskønitetene. Mange av festene viet Demeter er feiret av kvinner alene i hemmelighet, slik som det også foregår under pannychisritualet. Kvinner anses til å være bedre i stand til å utføre jordbruksmagi enn menn. De er nærmere forbundet med fruktbarhetens vekst, fordi de selv bærer, føder og nærer barn, og symboliserer fruktbarhet. Vanligvis anses kvinner for å ha en slags mystisk forståelse med naturkreftene, som de besitter som følge av deres egen biologi. Kvinnenes kunnskap om fruktbarhetsmagi betyr at de også har makt til å forhindre fruktbarheten, gjennom kunnskap om bruk av magiske planter i forlengelse av det mytiske forbildet Demeters makt. De har derfor hatt en kunnskap og makt menn generelt frykter, som følge av at de ikke har denne kunnskapen. Dette tar det mannlige verdisystemet konsekvensen av under Eleusismysteriene. Ære- og skamsamfunnets arbeidsdeling mellom kjønnene blir altså absolutt i fruktbarhetsfestens rituelle kontekst, siden fruktbarhet tilhører kvinnene, på samme måte som krigen tilhører mennene. Ifølge hymnen besøker den mannlige Plutos, dvs. overflod av markens grøde, huset til 
dem som gudinnen elsker (HHD. 486-489). Det kan være et forsøk på en mannlig regulering av gudinnens makt.

Her møter vi de omtalte paradoksene eller motsigelsene som er iboende i ære- og skamverdiene: Avhengigheten av kvinnen i denne kulturen der mannen er en allmektig kopi av Zeus illustreres når det hevdes at: "i den usikre tiden etter såtid må kvinnen sørge for at hennes parallell jorden gjør det den skal" (Bourdieu 1980, 377). I denne sammenhengen hører også hymnene viet Persefone (Ar. Ran. 377-382), den frelsende gudinnen (Ran. 378), og Demeter (Ran. 384-393), den høye og mektige gudinnen, innhøstingens dronning, korngiversken (Ran. 382 f.), som ble fremført under prosesjonen til Eleusis. Demeter blir ellers vurdert som Dronningen over alt, jorden, alle tings mor og amme inkludert. Hun er både den som gir liv og den infernalske, et aspekt som også hører sammen med den rasende gudinnens hevn for rovet av datteren. Dette er også forenelig med ære- og skamsamfunnets vurdering av kvinner, som de dels frykter, dels er tiltrukket av.

I Eleusismysteriene, som ellers i det mediterrane kjønnete sfæresamfunnet, er det en diskrepans mellom det mannlige ære- og skamideal som hevder at kvinnen skal være passiv og holde seg hjemme i huset og det reelle liv, for i motsetning til det mannlige idealet, er ikke kvinner passive, heller ikke de kvinnelige deltakerne i mysteriene. Ser en samfunnet fra et ære- og skamperspektiv, kan en derfor hevde at mannlige verdier utfordres av ditto kvinnelige. Ser en derimot samfunnet som bestående av to komplementære kjønnete sfærer, som både er adskilt og overlapper, er det betydningen av den kvinnelige komponent som her kommer frem. Fra et kvinnelig perspektiv, kan en da hevde at kvinnene gjør det de alltid har gjort, uten å spørre menn først, og derfor uten å se på dette som en utfordring av mannlige verdier. ${ }^{24}$ Mannlige forfatteres beskrivelse av kvinner er ikke nødvendigvis samsvarende med kvinners syn, slik vi opplever det ved å lese de få kilder vi har fra kvinner selv. Selv om Demeterhymnens 'opprinnelse' er uviss, har hymnen også et mer positivt syn på den kvinnelige part enn f.eks. Hesiod (Th.) og tragediene. Siden et viktig tema i hymnen er konflikten mellom Zeus og Demeter, som nekter jorden å spire, illustrerer hymnen både den årlige vegetasjonssyklusen, kvinnelig erfaring, gjennom Kores bryllup og en mors klagesang, foruten innstiftelsen av mysteriene av gudinnen som først viste seg for de stolte kvinnene i Eleusis. I hymnen ser en hva som skjer når menn blander seg inn i mor-datter-forholdet på en voldelig måte. Ved å sammenligne de strategiene som Demeter og Zeus bruker kan en se at Demeters moderlige politikk representerer en genuin utfordring til Zeus' patriarkalske politikk. Selv om det offisielt er faren som avtaler bryllupet, er det moren som velger sin svigersønn, bruddet på denne regelen vitner Demeters hevn om. Selv om den vanlige terminologien i dagens ære- og skamsamfunn sier at en 'tar' en brud, hevdes det også at en 'gir' (dino) en datter, og dette var ikke Demeter villig til. Overtredelsen av hennes vilje er årsaken til revansjen hen- 
nes og det Zeus må gi tilbake for å blidgjøre henne, så hun igjen lar jorden spire (HHD. 470-482, jf. 314-333).

Det er ikke uvanlig at kvinner, som en parallell til Demeters grunnlegging av mysteriene, grunnlegger kult i antikken, selv om kvinner skulle holde seg hjemme i huset ifølge ære- og skamkoden. Det kan være grunnen til at det i senere tradisjon fortelles at det var mannlige helter som grunnla mysteriene etter gudinnens besøk til minne om besøket. ${ }^{25}$ På den annen side, er hussfæren vid og kan, som i dag, utmerket godt inkludere det en nordeuropeer ville omtale som offentlige rom, som i en mediterran kontekst imidlertid er dominert av kvinner, i form av et kultområde viet gudinner. Prestinner har da også sentral betydning i Eleusismysteriene: Demeterprestinnen bodde i helligdommen, holdt tjenesten på livstid, var eponymos i Eleusis, dvs. gav navn til året, og konkurrerte noen ganger med hierofanten om visse privilegier. Andre sentrale kvinner var 'de allhellige' (panageis), og 'biene' (melissai).

Betydningen av prestinner i antikkens kult, har vært understreket av mange kvinnelige forskere, eksempelvis Joan Breton Connelly (2007), som imidlertid synes å mene at når kvinner 'blir som menn' (dvs. beveger seg på det som i tradisjonelle samfunn betraktes som mannlige bastioner) har de makt. Hun ser ikke at det kan være mye makt også i kvinnelige aspekter, som mat, hus og hjem. Det medfører at betydningen av kvinnens sentrale roller, nødvendigvis ikke innebærer at de er offentlige prestinner. Jeg har diskutert dette aspektet grundig annensteds (Håland 2007, kap. 6) og skal ikke gjenta meg selv, men påpeke at jeg der også diskuterer kvinnelige forskere som har hevdet at kvinnelige prester i mysteriene (som i andre mysteriekulter, som også oftest er viet gudinner og der deltakerne også er kvinner), vitner om en kultisk (og derfor kontrollert) motsetning til dagliglivets forvisning av kvinner til hjemmet, og derfor igjen bekrefter et patriarkalsk verdisystem. ${ }^{26}$ På den annen side, tar dette perspektivet det mannlige patriarkalske systemet for gitt, hvilket ikke nødvendigvis er korrekt mht. til det mediterrane kjønnete sfæresamfunnet, der også hus- eller hjemmesfæren, som alt nevnt, er mye videre enn privatsfæren i dagens moderne vestlige samfunn. Fra et annet perspektiv, kommer en derfor frem til betydningen av kvinners rolle, der modellen nettopp er hjemmesfæren, som ikke er en forvisning, men det viktige området der store deler av produksjonen (mht. liv, mat og helse) foregår i et før-indistruelt samfunn. Derfor må også disse faktorene nødvendigvis ha en stor betydning i det større samfunnet, dvs. mht poenget med mysteriefestene: de skal sikre maten. I antikken var model-

25 Jf. infra og n.34 for Parker 1996, 98 f.

26 Jeg vil gjerne takke den anonyme leseren av artikkelen for å ha minnet meg på at dette også gjelder f.eks. Froma I. Zeitlin mht. de dionysiske 'thyiade-ritene'. Jf. Zeitlin 1982. Dette blir også en parallell til tanken bak det 'omvendte ritualets logikk', der kvinner fremvises på den tragiske scenen for så å skyves tilbake til sine vanlige roller, slik som i senere karnevalsfeiringer og dagens afrikanske samfunn. En slik forklaring er basert på Max Gluckmans (1991) tese om at samfunnet 'står på hodet' eller snus opp ned, slik som under karneval, der såkalt svakere grupper får makt en kort periode, for deretter å gå tilbake til sin vanlige maktesløse tilværelse. Dette er kun tilfelle om en ser det ut fra et mannsperspektiv, der makt defineres gjennom å styre polis offisielt. 
len hjemmesfæren, versus dagens moderne samfunn der modellen er den offentlige sfæren, som inntil nylig har vært forbundet med menn, men der kvinnene har gjort sitt inntog etter hvert som hjemmesfærens makt har krympet. Det betyr da at vi ikke har en motsetning mellom hjemmet og det større samfunn, men gjennom et videre perspektiv ser at ritualene som generelt knyttes til hjemmesfæren er viktige for det større samfunn.

Mht. forskjellen mellom kvinnelige og mannlige verdier, kan den være universel127, og biologisk, selv om biologisk determinisme er et omstridt fenomen, og forholdet mellom biologi og kultur ikke er entydig. Mange vil nok mene at den er bestemt av en patriarkalsk kultur som transkenderer den mannlige elite. Jeg har alt argumentert for at kulten av en morgudinne ikke trenger å indikere matriarkat, like lite som fravær av matriarkat trenger å indikere patriarkat. ${ }^{28}$ Den kan også være historisk og strukturell som følge av sfærene i middelhavsområdet. ${ }^{29}$ Under alle omstendigheter samsvarer verdisynet hos antikkens og dagens menn i området. Der er også store likheter mellom verdisystemet hos dagens greske (særlig bonde) kvinner og de få kildene vi har fra antikkens kvinner. ${ }^{30}$ Vedrørende forskjellen mellom mannlige og kvinnelige verdier, som også er knyttet til deres forskjellige sfærer og roller, er det viktig å huske at kvinner erfarer verden annerledes enn menn og det derfor er vanskelig å klarlegge hvordan de oppfatter sine roller ved å lese mannlige kilder. ${ }^{31}$ En kan også sammenligne det eleusinske pannychis-ritualet med dagens forhold der kvinnene tar med seg klappestoler og går i kirken når prestenes rituale (jf. den offisielle ortodokse ideologiske liturgi) er ferdig. 32

Mannlige ære- og skamverdier legges altså ofte til side, selv om de kan høre hjemme i folkekulten og generelt er knyttet til kvinner og deres domener, slik som med symbolikken bak fargen på purpurbåndene som bandt sammen kistai (runde bokser) der en brakte hiera. Det gjelder også andre symboler som har magisk fruktbarhetsgivende betydning, som myrtegrenene ${ }^{33}$ og symbolikken bak pattegrisen alle mystene ofret. Purpurfargen og myrtegrener er vanlig i forbindelse med bryllup og innvielse. Funn alt fra steinalderen peker på forbindelsen mellom gris og korn. Siden grisen er et velkjent substitutt for kvinnelige genitalier, og et vanlig offer i Demeterfester, vitner den

27 Jf. f.eks. Keesing 1981; Jacobson-Widding/van Beek 1990; Håland red. 2008.

28 Her hører også Peggy Reeves Sanday, selv om jeg stiller meg tvilende til hennes matriarkatstese (2002), som også er populær blant dagens greske kvinnelige forskere (riktignok i tradisjonen etter Jane Harrison 1977), i likhet med patriarkatstesen, som er forbundet med det mannlige ideal, men som gjerne blir paradoksal i møte med det kvinnelige verdisystemet. Jeg mener derfor at et sfæresystem er et bedre utgangspunkt, jf. Håland 2007, kap. 6.

29 Jf. også Håland 2007, kap. 1 og 6 og f.eks. Gilmore 1987.

30 Jf. Håland 2007, 2008b.

31 Se også Håland 2008b.

32 Når de er i kirken under det nattlige ritualet (f.eks. mellom 14. og 15. august) og synger hymner for Panagia eller andre kvinnelige helgener, har de sin egen liturgi, jf. også Håland 2009.

33 Afrodites hellige plante var myrten, iflg. Plut. Mor. 268e. 
om seksualitet og er et klart fruktbarhetssymbol. Øvrige offergaver fra Demetertempelet er også relatert til kvinner.

Ifølge det mannlige verdisynet er følelser gjennom sorg og klager forbundet med kvinner, som også er de sentrale utøvere av dødsritualene. Før mystene ble innvidd i de prestisjefylte mysteriene, etterlignet de likevel Demeters sorg og faste ved tapet av datteren, fulgt av bruddet på fasten, da de drakk den omtalte kykeon. Dessuten hevder Aristoteles at de innvidde ikke lærer noe, men de føler noe (Arist. Fr. 15).

En møter altså flere tilfeller der mannlige ære- og skamverdier dels skjules, dels manifesteres, f.eks. gjennom det store mysteriet, hierofantens fremvisning av innholdet i de hellige kistene. Hiera skal ha vært en fallos og det kvinnelige kjønnsorganet, foruten et kornaks (Hippol. Haer. 5.8,39 f.; Clem. Al. Protr. 2.19P; Tert. Adv. Valent. 1.3), som var viktig i Demeterkulten. Her illustreres samme sammenblanding som i kykeon, som igjen er en parallell til forekomsten av et hieros gamos (hellig bryllup) i mysteriene, og den påfølgende annonseringen av en guddommelige fødsel. Slik symboliseres det forventete resultatet både av ekteskapet og såingen av kornmarken.

Som alt nevnt, illustreres mannlige verdier gjennom betydningen av det mannlig barnet i mysteriene. Demeter har en slags moderlig forbindelse med alle de betydningsfulle guttene i den eleusinske kulten og i hymnen, både Plutos, Iakchos, Triptolemos og Demofon. Likevel er det ikke et guttebarn, som er det viktigste barnet for Demeter i hymnen. Hymnen viser at en kvinne både ønsker seg en datter, og at hun er dyrebar for moren. Det er Kore som er Demeters barn i hymnen, og rovet av datteren som er årsaksmyten til innstiftelsen av mysteriene. Det viktigste barnet for Demeter er datteren, som hun vil ha tilbake, og Kores tilbakekomst blir synonymt med kornets tilbakekomst eller gjenfødsel innen jordbruksårets syklus.

\section{Konklusjon}

Siden Demeterhymnen gir den mytologiske rammen rundt mysteriene, blir dette en parallell til den moderne greske myten knyttet til pilegrimssenteret på øyen Tinos der Jomfru Maria, Panagia, viser seg for en nonne. Denne guddommelige, evige fortellingen er representert av kvinner og knyttet til en monumental eller syklisk tid, som imidlertid søkes knyttet til den generelle mannlig historiske lineære tiden relatert til den moderne greske nasjonalstaten. Slik kan en mytisk eleusinsk fortelling og tid knyttes til en athenske mannlig lineær historie. Den guddommelige mytiske monumentale tiden er også her knyttet til kvinner, gjennom gudinnen, datteren og de eleusinske kvinnene og synes å være 'innlagt' i Eleusismysteriene slik de fremkommer i klassisk tid. Det kvinnelige aspektet synes å være en slags grunnstamme. Slik kan en f.eks. forklare at en eventuell lokal eleusinsk versjon av den kvinnelige Thesmophoriefesten utvikles til Eleusismysteriene der både menn og kvinner kan delta. Da kan opprinnelsen henge igjen gjennom de ritualene som kvinnene fortsatt måtte fremføre, etter at Eleusis var blitt en del av den athenske polis. Det betyr da at vi kommer frem til 
kjernen i festen når vi tar for oss fraværet av mannlige verdier. Under alle omstendigheter er festen viet en fruktbarhetsgudinne som står nærmest kvinnene.

Eleusismysteriene presenterer altså ritualer der begge kjønn deltar, kvinnedominerte og mannligdominerte ritualer, og begge kjønns verdier. Grunnleggende trekk i kulten har dype røtter i tradisjonell folkekult, og har derfor vært viktig for alle lag av befolkningen. Følgelig må også mannlige verdier legges til side i mysteriene i sentrale sammenhenger, der det var de fruktbarhetsfremmende kvinnene som rådde grunnen i likhet med gudinnen festen var dedisert. Slik skulle maten sikres.

Samtidig vitner betydningen av hieros gamos i mysteriene at der er like liten grunn til å ekskludere den mannlige komponenten som tidligere kvinneforskning mente at antikkens menn erobret eller ekskluderte den kvinnelige komponent, ut fra en bokstavelig lesning av antikke kilder skrevet av menn. ${ }^{34}$ Det er viktig å ta hensyn til paradoksene eller motsigelsene i disse kildene. Artikkelen skulle ha vist at ære- og skamkoden er en ensidig forståelsesramme med et mannlig verdisystem knyttet til den mannlige sfæren, og den evner ikke å gi en helhetlig forståelse av festen og den kulturen den hører hjemme i. Det mannlige perspektivet må derfor nyttes sammen med et alternativt kvinnelig perspektiv, hvor det verdisystemet som legges til grunn hentes fra den greske kvinnesfæren. Ut fra en slik ktonisk vinkling kan en dekonstruere de mannligproduserte kildene og de mange paradoksene eller motsigelsenen de vitner om, og slik søke å gi en mer fullstendig fremstilling av samfunnet (jf. Håland 2007), for selv om denne artikkelen hovedsakelig har fokusert på å definere de mannlige verdiene en møter i antikken for så å diskuterer deres tilsynekomst i De eleusinske mysteriene, har den også tatt for seg de samme verdienes fravær i mysteriene, og dermed også behandlet de kvinnelige verdiene en møter i Eleusismysteriene.

34 Ut fra en bokstavelig lesning av mannsproduserte kilder generelt har duBois (1988) hevdet at kvinnekroppen ble 'annektert' av mannlige filosofer. Loraux 1989 har hevdet at det athenske demokrati var basert på annekteringen av det kvinnelige, kombinert med undertrykkingen av kvinnen. Zeitlin (1984) hevder at kontrollen over kvinnen var hjørnesteinen i sivilisasjonsprosessen, slik det fremstilles i Aiskhylos' Orestien, en trilogi som også er blitt ansett for å vitne om 'patriarkatets triumf'(Arthur 1977 og 1994). Mht. De eleusinske mysteriene, jf. n.25 supra og se Håland 2007, 260 for diskusjon av Parker 1996, 98f og kilder, som Xen. Hell. 6.3,6. Jf. også supra for kommentar til HHD 486-489 og vasemalerier fra ca. 540 f.v.t. (se supra). Det er neppe tvil om at en tidligere også har fokusert på mannlige lesninger av kildene som foreteller om mysterieritualene, f.eks. at Demeter gav kunnskapen om korndyrkingen til menn, selv om hun først viste seg i en genuint kvinnelig atmosfære iflg. HHD., og selv om hun er forbundet med mange guttebarn, er det datteren Kore som betyr mest for henne. Ellers har f.eks. Holst-Warhaft (1992) hevdet at etableringen av Eleusis-mysteriene var en kalkulert kompensasjon for kvinners tapte autoritet i ritualene viet de døde, en som plasserte dem under statens kontroll, se Håland 2007, kap. 6 for diskusjon. 


\section{LITTERATUR}

\section{PRIMÆRKILDER (INKL. FORKORTELSER)}

Aeschylus, Agamemnon, Libation-Bearers, Eumenides, Fragments. overs. Herbert Weir Smyth 1946 (1926), Bd. 2. The Loeb Classical Library. London (Heinemann).

Ar.=Aristophanes, The Peace, The Birds, The Frogs (=Ran.). overs. Benjamin Bickley Rogers 1950 (1924), Bd. 2. The Loeb Classical Library. Cambridge Mass. (Harvard University Press).

Arist. GA.=Aristotle, Generation of Animals. overs. A. L. Peck 1963 (1942). The Loeb Classical Library. London (Heinemann)

--- Pol.=Politics. overs. H. Rackham 1950 (1932). The Loeb Classical Library. London (Heinemann).

--- Qui Ferebantur Librorum Fragmenta. ed. Valentinus Rose 1886, Leipzig.

Clem Al. Protr.=Clement of Alexandria, The Exhortation to the Greeks. The rich man's salvation. overs. G. W. Butterworth 1953 (1919). The Loeb Classical Library. Cambridge Mass. (Harvard University Press).

Dem.=Demosthenes, Orationes. overs. C. A. Vince \& J. H. Vince 1926, Bd. 2. The Loeb Classical Library. Cambridge Mass. (Harvard University Press).

Eur.=Euripides, Bacchanals (=Bacch.), Madness of Hercules, Children of Hercules, Phoenician Maidens, Suppliants. overs. Arthur S. Way 1950 (1912), Bd. 3. The Loeb Classical Library. London (Heinemann).

Hdt.=Herodotus. overs. A. D. Godley 1924, Bd. 4. The Loeb Classical Library. Cambridge Mass. (Harvard University Press).

Hesiod Th./HHD.=Hesiod, The Homeric Hymns and Homerica. overs. H. G. Evelyn-White 1950 (1914). The Loeb Classical Library. London (Heinemann).

Hippol. Haer.=Hippolytus, Refutatio Omnium Haeresium. ed. Miroslav Marcovich 1986, Patristische Texte und Studien Bd. 25, Berlin (Walter de Gruyter).

IG=Inscriptiones Graecae. Consilio et auctoritate. Academiae litterarum Borussicae ed. 19271977. Inscriptiones Atticae Euclidis anno posteriores. Berolini (Walteri de Gruyter et Soc).

Il.=Homer, The Iliad. overs. A. T. Murray 1946, 1947 (1924, 1925), Bd. 1-2. The Loeb Classical Library. Cambridge Mass. (Harvard University Press).

Isoc.=Isocrates. overs. George Norlin 1954 (1928), Bd. 1. The Loeb Classical Library. Cambridge Mass. (Harvard University Press).

Od.=Homer, The Odyssey. overs. A. T. Murray 1946 (1919), Bd. 1-2. The Loeb Classical Library. Cambridge Mass. (Harvard University Press).

Paus.=Pausanias, Description of Greece. overs. W. H. S. Jones 1955 (1918), Bd. 1. The Loeb Classical Library. London (Heinemann).

PGM=The Greek Magical Papyri in Translation. Including the Demotic Spells. ed. Hans Dieter Betz, 1986, Bd. 1, Texts. Chicago/London (the University of Chicago Press).

Pl. Leg.= Plato, The Laws. overs. R. G. Bury 1952 (1926), Bd. 1-2. The Loeb Classical Library. London (Heinemann).

Plut. Mor.=Plutarch, Moralia. overs. Frank Cole Babbit et al., 1928-1959, Bd. 2, 4-7, 10. The Loeb Classical Library. Cambridge Mass. (Harvard University Press).

--- Sol., Per.=Plutarch, Lives. overs. B. Perrin 1948 (1914, 1916), Bd. 1, 3. The Loeb Classical Library. Cambridge Mass. (Harvard University Press).

Schol. Ar. Lys.=Scholia Græca in Aristophanem. ed. Fr. Dübner 1855, Paris (Ambrosio Firmin Didot).

Schol. Luc. DMeretr.= Scholia in Lucianum. ed. Hugo Rabe 1906, Leipzig. 
Tert. Ad. Nat.=Tertulliani, Opera, Pars 1. Opera Catholica; Adversus Marcionem. Corpus

Christianorum. Series Latina; 1, 1953, Turnholti (Brepols).

--- Adv. Valent.=Tertullien, Contre les Valentiniens. overs. Jean-Claude Fredouille 1980, Bd. 1.

Sources Chrétiennes. Paris (Les Éditions du Cerf).

Xen. Hell.=Xenophon, Hellenica. overs. Carleton L. Brownson 1921, Bd. 2. The Loeb Classical Library. London (Heinemann).

\section{SEKUNDÆRLITTERATUR}

Alexakes, Eleuth. P.

1990 E semaia sto gamo: Teletourgia - Exaplose - Proeleuse (Symbolet i bryllupet: ritual - utbredelse opprinnelse), Athen.

Arthur, Marylin

1977 "Politics and Pomegranates: An Interpretation of the Homric Hymn to Demeter", Arethusa 10, 7-47 (finnes også i Foley, ed. 1994, 212-242).

Blomqvist, K.

1995 "Chryseïs and Clea, Eumetis and the Interlocutress. Plutarch of Chaeronea and Dio Chrysostom on Women's Education", Svensk Exegetisk Arsbok 60, 173-190.

Bourdieu, Pierre

1980 Le Sens Pratique, Les Éditions de Minuit, Paris.

Connelly, Joan Breton

2007 Portrait of a priestess: women and ritual in Ancient Greece, Princeton University Press, Princeton.

Cuffel, Alexandra

2005 "From Practice to Polemic: shared saints and festivals as 'women's religion' in the medieval Mediterranean", The Bulletin of the School of Oriental and African Studies 68 (3), 401-419.

Dodds, E. R

1951 The Greeks and the irrational, University of California Press, Berkeley.

Dubisch, Jill

1991 "Men's Time and Women's Time: History, Myth, and Ritual at a Modern Greek Shrine", Journal of Ritual Studies 5 (1), 1-26.

duBois, Page

1988 Sowing the body. Psychoanalysis and Ancient Representations of Women, The University of Chicago Press, Chicago.

du Boulay, Juliet

1984 "The blood: Symbolic relationships between descent, marriage, incest prohibitions and spiritual kinship in Greece", Man 19, 533-556.

Foley, Helene P.

1994a ed., The Homeric Hymn to Demeter: Translation, commentary, and interpretive essays, Princeton University Press, Princeton

1994b "Preface and Acknowledgments. Part 1. The text and translation, commentary, and Background, Part 2, Interpretive essay on the Homeric Hymn to Demeter", in: Foley, ed., The Homeric Hymn to Demeter: Translation, commentary, and interpretive essays, xi-xvi, 1-178.

Foster, George M.

1972 "The Anatomy of Envy: A Study in Symbolic Behaviour", Current Anthropology 13 (2), 165-202.

Gilmore, David, ed.

1987 Honour and Shame and the Unity of the Mediterranean. American Anthropological Association, 22, Washington, D.C. 
Gluckman, Max

1991 Custom and Conflict in Africa, Blackwell, Oxford [1956].

Harrison, Jane Ellen

1977 Themis, Merlin, London (oppr. Cambridge 1912).

Herzfeld, Michael

1992 Anthropology through the looking-glass: Critical ethnography in the margins of Europe, Cambridge University Press, Cambridge [1987].

Holst-Warhaft, Gail

1992 Dangerous Voices: Women's Laments and Greek Literature. Routledge, London and New York.

Håland, Evy Johanne

1999 "Women, Death and the Body: in some of Plutarch's writings from the Hellenistic world", upublisert artikkel, Bergen, 20 sider.

2006 "The ritual year as a woman's life: The festivals of the agricultural cycle, life-cycle passages of Mother Goddesses and fertility-cult", in: George Mifsud-Chircop, ed., First International Conference of the SIEF working group on The Ritual Year. In association with The Department of Maltese University of Malta, Junior College, Msida, Malta, 2005: Proceedings, Publishers Enterprises Group (PEG) Ltd, Malta, 303-326.

2007 Greske fester, Moderne og Antikke: En sammenlignende undersøkelse av kvinnelige og mannlige verdier (Dr.avhandling, Universitetet i Bergen 2004), Høyskoleforlaget, Kristiansand.

2008a Konkurrerende ideologier i gresk religion før og nå, upublisert bokmanus, Bergen, ca. 250 sider.

2008b "Greek Women and Death, ancient and modern: A Comparative Analysis", in: E. J. Håland, ed., Women, Pain and Death: Rituals and Everyday-Life on the Margins of Europe and Beyond, Cambridge Scholars Publishing, Newcastle upon Tyne, 34-62.

2009 "The ritual Year of the Miraculous Icon on the Aegean sacred island of Tinos", kommer Folklore. Electronic Journal of Folklore (Mare Koiva \& Andres Kuperjanov, eds.), Tartu (Estland).

Jacobson-Widding, Anita \& Walter van Beek, eds.

1990 The Creative Communion: African Folk Models of Fertility and the Regeneration of Life, Uppsala Studies in Cultural Anthropology, Uppsala.

Keesing, Roger M.

1981 Cultural Anthropology: A Contemporary Perspective, New York [1976]

Kristeva, Julia

1986 “Women's Time", in: Toril Moi, ed., The Kristeva Reader, Basil Blackwell, Oxford, 187-213.

Loraux, Nicole

1989 Les Expériences de Tirésias. Le féminin et l'homme grec, Gallimard, Paris.

Moxnes, Halvor

1997 "Conventional Values in the Hellenistic World: 'Masculinity'”, in: Per Bilde, et al. eds., Conventional Values of the Hellenistic Greeks, Aarhus University Press, Århus, 263-284.

Papamichael, Anna J.

1975 Birth and Plant symbolism. Symbolic and magical uses of plants in connection with birth in modern Greece, 113, Asklipiou, Athen.

Parker, Robert

1996 Athenian Religion: A History, Clarendon Press, Oxford.

Patterson, Cynthia

1992 "Plutarch's 'Advice on Marriage': Traditional Wisdom through a Philosophic Lens", Aufstieg und Niedergang der römischen Welt II/33.6, 4709-4723.

Peristiany, J. G., ed.

1966 Honour and Shame: The Values of Mediterranean Society, University of Chicago Press, Chicago.

Pomeroy, Sarah B

1998 Families in Classical and Hellenistic Greece: Representations and Realities, Clarendon Press, Oxford. 


\section{Reeves Sanday, Peggy}

2002 Women at the Center: Life in a Modern Matriarchy, Cornell University Press, Cornell.

Stehle Stigers, Eva

1981 "Sappho's Private World", in: Helene P. Foley, ed., Reflections of Women in Antiquity, Gordon and Breach Science Publishers, New York - London - Paris, 45-61.

Vernier, Bernard

1991 La Genèse sociale des Sentiments: Ainés et cadets dans l'ile grecque de Karpathos, Éditions de l'école des hautes études en science sociales, Paris.

Winkler, John J.

1990 The Constraints of Desire: The Anthropology of Sex and Gender in Ancient Greece, Routledge, New York, London.

Zeitlin, Froma I.

1982 "Cultic models of the female: Rites of Dionysus and Demeter", Arethusa 15, 129-157.

1984 "The Dynamics of Misogyny: Myth and Mythmaking in the Orestia", in: John Peradotto \& J. P. Sullivan, eds., Women in the Ancient World. The Arethusa Papers, State University of New York Press, Albany, 159-194

Evy Johanne Håland, dr. i historie, freelance forsker Bergen, Norge 